\title{
Using the pathogen-host interactions database (PHI-base) to investigate plant pathogen genomes and genes implicated in virulence
}

\author{
Martin Urban *, Alistair G. Irvine, Alayne Cuzick and Kim E. Hammond-Kosack \\ Department of Plant Biology and Crop Science, Rothamsted Research, Harpenden, UK
}

New pathogen-host interaction mechanisms can be revealed by integrating mutant phenotype data with genetic information. PHI-base is a multi-species manually curated database combining peer-reviewed published phenotype data from plant and animal

\section{OPEN ACCESS}

Edited by:

Dan MacLean

The Sainsbury Laboratory, UK

Reviewed by:

Ana Elena Dorantes-Acosta, Universidad Veracruzana, Mexico

Oliver Furzer,

University of East Anglia, UK

${ }^{*}$ Correspondence: Martin Urban

Department of Plant Biology and Crop Science, Rothamsted Research, West Common, Harpenden, Herts AL5

2JQ, UK

martin.urban@rothamsted.ac.uk

Specialty section:

This article was submitted to Plant Genetics and Genomics,

a section of the journal

Frontiers in Plant Science

Received: 11 May 2015

Accepted: 22 July 2015

Published: 06 August 2015

Citation:

Urban M, Irvine AG, Cuzick A and Hammond-Kosack KE (2015) Using

the pathogen-host interactions

database (PHI-base) to investigate

plant pathogen genomes and genes implicated in virulence.

Front. Plant Sci. 6:605.

doi: 10.3389/fpls.2015.00605 pathogens and gene/protein information in a single database.

Keywords: gene regulatory networks, plant diseases, protein interaction mapping, genetic recombination, comparative genomics, horizontal gene transfer, phytopathogens, emerging diseases

PHI-base is a multi-species knowledge database capturing the phenotypes available on forward and reverse mutants from 231 pathogenic organisms described in the literature. Plant pathogens represent $60 \%$ of the species within PHI-base. Simple and advanced search tools, available at www.phi-base.org, allow users to query PHI-base directly. Flat file downloads enable larger comparative biology studies, systems biology approaches and a richer annotation of genomes, transcriptomes and proteome data sets. Since 2014, phenotype information from PHIbase is directly displayed in pathogen genome browsers accessible at www.phytopathdb.org (Kersey et al., 2014). PHI-base regularly interacts with the international community to provide researchers with effective query tools and new data types to study pathogen-host interactions.

Available online since 2005, PHI-base catalogs experimentally verified pathogenicity, virulence and effector genes from fungal, protist, and bacterial pathogens which infect animal, plant, fish, insect, and/or fungal hosts (Urban et al., 2015). PHI-base is a database devoted to the identification and presentation of information on pathogenicity and effector genes and their host interactions. PHI-base was developed out of a need for a knowledge database enabling the discovery of candidate targets in medically and agronomically important species for intervention with chemistries and/or host modifications. Recent bioinformatics studies enabled by wholedatabase downloads of PHI-base, include comparative analyses, genome/transcript and proteome annotations, and system biology approaches (Hu et al., 2014; Zhang et al., 2014). PHI-base has been cited in 122 published articles including genetics, genomics and bioinformatics research and review articles (for an up-to-date list, see the "About" page of the PHI-base website). In 2014, the web site had more than 6000 visits and the entire content was downloaded $>300$ times. Phenotypic outcome data from PHI-base are also displayed directly in genome browsers as permanent tracks in public genome sequence resources such as Ensembl Fungi (Figure 1). Through a simple system of color coding and using nine high level PHI-base phenotypes (Urban et al., 2015), genomic features such as pathogenicity islands can directly be investigated. 


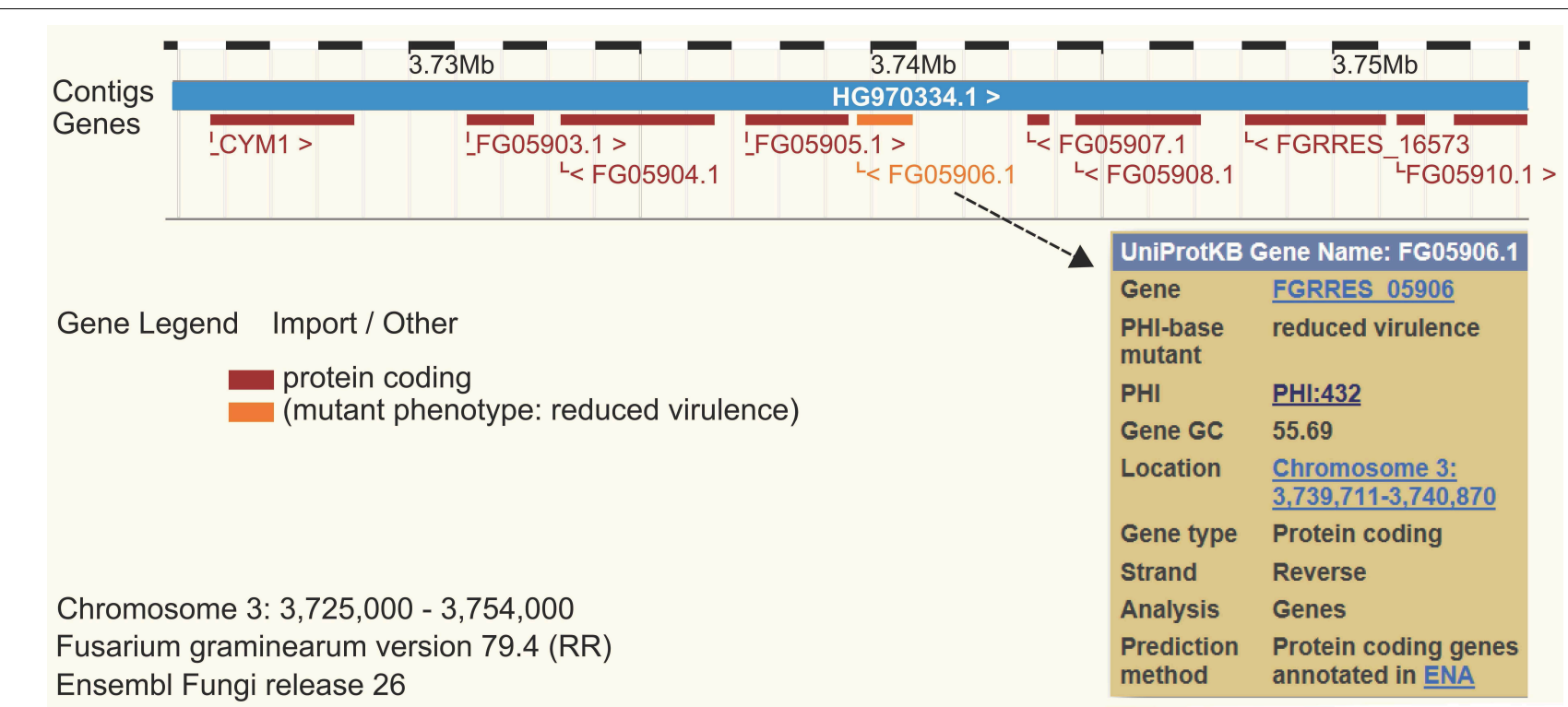

FIGURE 1 | Ensembl genome browser view for Fusarium graminearum. The website at http://fungi.ensembl.org/ Fusarium_graminearum was searched for the gene id FGSG_05906

TABLE 1 | Top 10 plant pathogen species in PHI-base.

\begin{tabular}{|c|c|c|}
\hline Species & Genes curated & Interactions curated \\
\hline Fusarium graminearuma & 966 & 1078 \\
\hline Magnaporthe oryzae ${ }^{b}$ & 423 & 662 \\
\hline Ustilago maydis & 197 & 252 \\
\hline Botrytis cinereac & 86 & 210 \\
\hline Pseudomonas syringae & 73 & 140 \\
\hline Fusarium oxysporum & 58 & 85 \\
\hline Hyaloperonospora arabidopsidis ${ }^{\mathrm{d}}$ & 55 & 67 \\
\hline Zymoseptoria triticie & 41 & 42 \\
\hline Parastagonospora nodorum ${ }^{f}$ & 40 & 46 \\
\hline Leptosphaeria maculans & 17 & 21 \\
\hline
\end{tabular}

Species name synonyms.

${ }^{a}$ Gibberella zeae.

${ }^{b}$ Magnaporthe grisea.

${ }^{c}$ Botryotinia fuckeliana.

${ }^{a}$ Hyaloperonospora parasitica or Peronospora parasitica.

${ }^{e}$ Mycosphaerella graminicola or Septoria tritici.

${ }^{f}$ Stagonospora nodorum, Phaeosphaeria nodorum, or Septoria nodorum.

The latest PHI-base release, version 3.8, contains a total of 3562 pathogen genes tested in 3697 plant- and 1257 animal-pathogen interactions. The top 10 plant pathogens are listed in Table 1. The data in PHI-base is obtained by biocuration scientists who extract the relevant information from peer-reviewed published articles in a manual curation workflow that includes the evaluation of full text, figures and tables, to create computable data records using controlled vocabularies and ontologies. This approach generates a encoding the secreted lipase gene Fgfg/1. The PHI-base phenotype of the mutant is displayed and color coded in orange as "reduced virulence." unique level of detail and breadth compared to automated approaches and thus provides instant access to a catalog of gold standard curated gene/protein function and host phenotypic information. Various complementary multi-species databases on pathogens exist that provide gene function annotation. Each specializes in particular species/pathogen groups and/or uses only automated approaches to knowledge acquisition (Table 2). Other resources are more geared to the analysis of host-pathogen interactions by providing protein-protein interaction (PPI) data, transcriptomics and genome assembly datasets or provide WEB portal linking to multiple databases and providing advanced analysis tools.

Future plans for PHI-base include the development of an online tool to allow author curation of published pathogenhost interactions from any pathogenic species. This new feature will be based on the Canto curation tool for PomBase (Rutherford et al., 2014). A refined PHI-base website will become available in 2015 to allow the display of additional manually curated information, including data on host target genes/ proteins.

\section{Funding}

This work is supported by the UK Biotechnology and Biological Sciences Research Council (BBSRC) (BB/I001077/1, BB/I000488/1, BB/K020056/1). PHI-base receives additional support from the BBSRC as a National Capability (BB/J004383/1). Funding for the open access charge was obtained from the Research Councils UK Open Access Fund. 
TABLE 2 | Synopsis of complementary multi-species pathogen databases and their specialisms ${ }^{\mathrm{a}}$.

\begin{tabular}{llll}
\hline Database Content & URL (http://) Comments
\end{tabular}

\begin{tabular}{|c|c|c|c|}
\hline \multicolumn{4}{|c|}{ MULTI-SPECIES DATABASES PROVIDING GENE FUNCTION ANNOTATION } \\
\hline AgBase & $\begin{array}{l}12 \text { animals, } 7 \text { plant, } 26 \text { microbial species } \\
\text { including } 15 \text { viruses }\end{array}$ & agbase.msstate.edu & $\begin{array}{l}\text { Agricultural plant and animal gene products } \\
\text { database with a focus on } \mathrm{GO} \text { annotation }\end{array}$ \\
\hline CPGR & $\begin{array}{l}138 \text { plant pathogen genomes and } \\
\text { transcript collections }\end{array}$ & cpgr.plantbiology.msu.edu/index.html & $\begin{array}{l}\text { The comprehensive phytopathogen } \\
\text { genomics resource is focused on enabling } \\
\text { the development of diagnostic molecular } \\
\text { markers }\end{array}$ \\
\hline
\end{tabular}

\begin{tabular}{|c|c|c|c|}
\hline DFVF & 2048 genes & sysbio.unl.edu/DFVF & $\begin{array}{l}\text { Covers fungal pathogen genes and virulence } \\
\text { factors acquired using a text-mining } \\
\text { approach }\end{array}$ \\
\hline
\end{tabular}

PHIDIAS 36 species www.phidias.us

Pathogen-host interaction data integration and analysis system with focus on human and animal priority pathogens with regard to public health

VFDB 25 species www.mgc.ac.cn/NFs

Focus on virulence factors of human and animal bacterial pathogens

\section{PROTEIN-PROTEIN INTERACTION DATABASES}

Host-Pseudomonas aeruginosa and Coxiella burnetti interaction DataBase is manually curated with focus on mammalian, Drosophila melanogaster or Danio rerio generated data

The host-pathogen interaction database focused on experimental protein-protein interactions from diverse mammalian and plant hosts infected by influenza, bacteria and fungi

\begin{tabular}{|c|c|c|}
\hline \multicolumn{3}{|c|}{ TRANSCRIPTOMICS DATABASES } \\
\hline PLEXdb & Vast, includes 12 fungal pathogens & www.plexdb.org \\
\hline Eumicrobedb & Vast & www.eumicrobedb.org/transcripts \\
\hline \multicolumn{3}{|l|}{ GENOME BROWSERS } \\
\hline Broad-fungal genomics & >100 species & $\begin{array}{l}\text { http://www.broadinstitute.org/scientific- } \\
\text { community/science/projects/fungal-genome- } \\
\text { initiative }\end{array}$ \\
\hline
\end{tabular}

Transcriptomics database only on plants, pathogens and their interactions

Oomycetes transcriptomics database providing transcriptome and EST data organisms including human and plant pathogens. Gene annotation searchable by keyword. Includes non-pathogenic species

Ensembl genomes Vast number of genomes www.ensemblgenomes.org

Non-vertebrate species genome browser suite with dedicated sub-portals for bacteria, fungi, protists, and plants species. PHI-base phenotypes directly displayed in individual genome browsers and accessible via the multiple species analysis tool BioMart

JGI-mycoCosm Vast number of genomes $\quad$ genome.jgi.doe.gov/programs/fungi

A genome portal for $100 \mathrm{~s}$ of pathogenic and non-pathogenic fungal species. No association of phenotypes to genes, but possible to search by keyword and GO annotation 
TABLE 2 | Continued

\begin{tabular}{|c|c|c|c|}
\hline Database & Content & URL (http://) & Comments \\
\hline \multicolumn{4}{|l|}{ WEB PORTALS } \\
\hline EuPathDB & $\begin{array}{l}\text { Links to } 11 \text { other single and multi-species } \\
\text { databases }\end{array}$ & eupathdb.org & $\begin{array}{l}\text { Eukaryotic pathogen database resource for } \\
\text { biodefense and infectious diseases on } \\
\text { human pathogens providing an analysis tool } \\
\text { kit to linked resources }\end{array}$ \\
\hline Pathogen portal & Links to 5 database centers & www.pathogenportal.org & $\begin{array}{l}\text { Focus is on pathogens as potential agents of } \\
\text { biowarfare or bioterrorism and organisms } \\
\text { causing (re)emerging infectious diseases } \\
\text { (bacteria, viruses, and eukaryotes) }\end{array}$ \\
\hline Phytopath & web portal & www.phytopathdb.org & $\begin{array}{l}\text { Ensembl genomes browser made available } \\
\text { as a theme group for plant pathogens. } \\
\text { Phenotypic information is directly displayed } \\
\text { for } 32 \text { Fungi, } 14 \text { Protists, } 12 \text { bacterial species }\end{array}$ \\
\hline
\end{tabular}

${ }^{a}$ virus only databases not included.

\section{Acknowledgments}

The authors would like to thank all contributing scientists, who provided expert knowledge by reviewing PHI-base data and suggesting articles for curation. We thank Drs Helder Pedro, Paul Kersey, Uma Maheswari, and

\section{References}

Hu, X., Xiao, G., Zheng, P., Shang, Y., Su, Y., Zhang, X., et al. (2014). Trajectory and genomic determinants of fungal-pathogen speciation and host adaptation. Proc. Natl. Acad. Sci. U.S.A. 111, 16796-16801. doi: 10.1073/pnas.14126 62111

Kersey, P. J., Allen, J. E., Christensen, M., Davis, P., Falin, L. J., Grabmueller, C., et al. (2014). Ensembl Genomes 2013: scaling up access to genome-wide data. Nucleic Acids Res. 42, D546-D552. doi: 10.1093/nar/gkt979

Rutherford, K. M., Harris, M. A., Lock, A., Oliver, S. G., and Wood, V. (2014). Canto: an online tool for community literature curation. Bioinformatics 30, 1791-1792. doi: 10.1093/bioinformatics/btu103

Urban, M., Pant, R., Raghunath, A., Irvine, A. G., Pedro, H., and HammondKosack, K. E. (2015). The pathogen-host interactions database (PHI-base): additions and future developments. Nucleic Acids Res. 43, D645-D655. doi: 10.1093/nar/gku1165
Dan Staines at the European Bioinformatics Institute (Cambridge, UK) for discussions and significantly improving the pathogen species content within Ensembl Genomes. Rashmi Pant and Arathi Raghunath at Molecular Connections (Bangalore, India) are thanked for expert data capture.
Zhang, Y., Zhang, K., Fang, A., Han, Y., Yang, J., Xue, M., et al. (2014). Specific adaptation of Ustilaginoidea virens in occupying host florets revealed by comparative and functional genomics. Nat. Commun. 5, 3849. doi: $10.1038 /$ ncomms 4849

Conflict of Interest Statement: The authors declare that the research was conducted in the absence of any commercial or financial relationships that could be construed as a potential conflict of interest.

Copyright (c) 2015 Urban, Irvine, Cuzick and Hammond-Kosack. This is an openaccess article distributed under the terms of the Creative Commons Attribution License (CC BY). The use, distribution or reproduction in other forums is permitted, provided the original author(s) or licensor are credited and that the original publication in this journal is cited, in accordance with accepted academic practice. No use, distribution or reproduction is permitted which does not comply with these terms. 